\title{
Evidence, Regulation, and Consequences of Nitrogen-Driven Nutrient Demand by Turfgrass
}

\author{
Wayne R. Kussow, Douglas J. Soldat, William C. Kreuser, and Steven M. Houlihan \\ Department of Soil Science, University of Wisconsin, 1525 Observatory Drive, Madison, WI 53706-1299, USA \\ Correspondence should be addressed to Douglas J. Soldat, djsoldat@wisc.edu
}

Received 21 October 2011; Accepted 13 November 2011

Academic Editors: J. T. Tsialtas and H. Zhang

Copyright ( $) 2012$ Wayne R. Kussow et al. This is an open access article distributed under the Creative Commons Attribution License, which permits unrestricted use, distribution, and reproduction in any medium, provided the original work is properly cited.

\begin{abstract}
Nutrient uptake is strongly influenced by plant growth rate. Accelerated growth leads to nutrient levels incapable of sustaining the optimal growth rate, resulting in shoot to root signaling for increased nutrient absorption. The factors controlling nutrient demand in turfgrass and its consequences have not been investigated. The objectives of this research were to verify that turfgrass exhibits the principal characteristics of demand-driven nutrient uptake and to identify the primary factor controlling nutrient demand via regulation of growth rates. Kentucky bluegrass clipping production increased linearly up to annual fertilizer $\mathrm{N} \mathrm{rates} \mathrm{of} 600 \mathrm{~kg}^{-1}$ and to $1000 \mathrm{~kg} \mathrm{~N} \mathrm{ha}^{-1}$ for creeping bentgrass. At the typical annual $\mathrm{N}$ fertilization rates of 150 to $300 \mathrm{~kg} \mathrm{ha}^{-1}$ for the two grasses, $\mathrm{N}$ supply was the primary determinant of turfgrass growth rate, plant nutrient demand, and nutrient uptake. Nitrogen uptake accounted for over $88 \%$ of uptake of all other nutrients. Uptake of $\mathrm{P}$ and $\mathrm{K}$ were strongly related to tissue $\mathrm{N}$ content irrespective of soil test levels. Variations in turfgrass species and cultivar nutrient requirements and nutrient use efficiencies were found to be directly related to differences in growth rates and, by inference, to differences in nutrient demand.
\end{abstract}

\section{Introduction}

Nutrient demand is well established as having strong control over plant responses to varying external nutrient supplies [14]. Nye and Tinker [5] were among the first to articulate a definition of nutrient demand. Drawing from the pioneering research of Williams [6] and subsequent work by Clarkson [7], Lonergan and Asher [8] Nassery [9], Pitman [10], and White $[11,12]$, they defined nutrient demand as a plant property directly arising from changes in plant weight and composition that is expressed at root surfaces and relies on strong feedback control of root activity by the rest of the plant, possibly triggered by changes in the amounts of cytosol carbohydrates and inorganic nutrients in the root or shoot.

Details of how plant shoot growth triggers expression of nutrient demand in roots are being intensively researched. White [12] hypothesized that the influx of P into root cortical cells is regulated by the turnover rate of inorganic $\mathrm{P}$ in the cytoplasm and the rate of transport to shoots. Cooper and Clarkson [13] and Marschner et al. [14] have confirmed the rapid xylem-phloem cycling and recycling of nutrient ions and certain metabolites in plants, thereby lending credence to White's [12] hypothesis. This rapid cycling and recycling of nutrient ions and metabolites has become accepted as the basic means whereby shoot to root signaling of whole plant nutrient status is achieved and leads to integration of root membrane nutrient absorption rates with whole plant nutrient demand [13].

Activation of ion uptake by roots is thought to result from the influences of fluctuations in cytosol contents of nutrient ions or metabolic products such as glutamine [15] or glutathione [16] on the functioning of one or more of the three classes of ion transporters-channels, pumps and receptors-all residing in root cell membranes. Suggested means whereby this occurs include energization of transport proteins by electrochemical proton gradients [17] or transducing molecules [16], the switching of gated ion transport channels [18] and cotransport to maintain cytosol charge balance $[19,20]$.

The level or intensity of plant demand for a nutrient is directly proportional to the difference between its plant tissue nutrient content at any given moment and that required 
to sustain an optimal growth rate [15]. Hence, unsatisfied nutrient demand in a plant is very high when the external nutrient supply is far below that enabling the plant to meet its physiological requirements but approaches zero as nutrient supply becomes sufficient to meet the demand established by the current rate of plant growth [12]. When unsatisfied nutrient demand exists, nutrient uptake rate is more closely related to plant growth rate than external nutrient concentration and indirectly determines uptake from a given level of external supply [1-3]. Once external nutrient supplies are sufficient to meet plant demand, long-term uptake and tissue nutrient content typically remain constant with further increases in the external supplies [21]. When external nutrient supplies are suboptimal with respect to plant demand and demand increases due to enhanced plant production potential, tissue nutrient content increases [22].

Recognition of growth-driven nutrient demand in turfgrass and what controls it has the potential for advancing understanding of many of the nuances of turfgrass responses to changes in external nutrient supplies. Variable nutrient demand at a fixed soil supply may account for difficulties encountered in soil test calibrations and interpretations for turfgrass [23], for reported differences in turfgrass species and cultivar nutrient requirements and nutrient use efficiencies [24-26], for lack of relationships between tissue cation and soil exchangeable cation concentrations [27, 28], and for lack of K luxury consumption by turfgrass [29].

Despite these many potential manifestations and consequences, the significance of nutrient demand has not been thoroughly investigated for turfgrass. The primary objectives of this research were to assemble evidence that nutrient utilization by turfgrass has the characteristics of demand driven uptake, to ascertain the principal factors regulating turfgrass growth rates and nutrient demand, and to apply the concept in the interpretation of published results from turfgrass nutrition studies.

\section{Materials and Methods}

This report draws upon the results of field experiments conducted over a period of several years at the University of Wisconsin O.J. Noer Turfgrass Research and Education Facility located near Madison, WI, USA and soil and clippings gathered from golf courses throughout the state of WI. A brief description of each of four individual experiments follows.

\subsection{Experiment 1: Soil Test Calibrations for Golf Putting} Greens. Paired soil and clipping samples were collected from 419 putting greens on golf courses located throughout Wisconsin during the 2001 and 2002 growing seasons for the purpose of improving soil test calibrations. The golf course superintendents were given instructions for collecting the clippings on specific dates. On those dates, a researcher visited the golf course(s) to pick up the clippings and collect soil samples from the respective putting greens. Composite soil samples consisting of 20 randomly selected cores were taken to a $10 \mathrm{~cm}$ depth with a $1.6 \mathrm{~cm}$ diameter probe. The clipping and soil samples were transported that same day to the University of Wisconsin-Madison for processing and analysis.

The soil samples were dried at $65^{\circ} \mathrm{C}$, ground to pass through a 10-mesh sieve, and analyzed for Bray-1 P and $\mathrm{K}$ [30] by way of inductively coupled plasma-optical emission spectroscopy (ICP-OES). The grass clippings were at $65^{\circ} \mathrm{C}$ for 48 hours and then cleaned, first by hand removal of foreign matter and then by sieving and passing through a seed cleaner adjusted to remove contaminating soil. The cleaned clippings were ground in a stainless steel chambered Wiley mill outfitted with a 40 -mesh sieve. Tissue N content was determined using the method of Bremner and Mulvaney [31]. Tissue samples digested with concentrated $\mathrm{HNO}_{3}$ and $\mathrm{H}_{2} \mathrm{O}_{2}$ [32] were analyzed for $\mathrm{P}, \mathrm{K}, \mathrm{Ca}, \mathrm{Mg}, \mathrm{S}$, and micronutrients by ICP-OES at the Wisconsin State Soil and Plant Analysis Laboratory (SPAL) in Verona, WI, USA.

Inspection of data from the 419 Wisconsin putting greens indicated that few if any of the greens had deficiency levels of nutrients. This led to the May 2003 reconstruction of a putting green for the purpose of creating what were deemed to be growth limiting levels of soil test $\mathrm{P}$ and $\mathrm{K}$. Site preparation began with the removal of the existing sod to a $10 \mathrm{~cm}$ depth from a $10.9 \times 16.4 \mathrm{~m}$ putting green constructed in 1992 according to USGA standards [33]. The upper $15 \mathrm{~cm}$ of root zone was removed to eliminate spatial differences that may have developed over the previous 11 years of use for research. The remaining $15 \mathrm{~cm}$ of root zone mix was mixed repeatedly with a tractor-mounted rotary tiller. The green was then capped with $15 \mathrm{~cm}$ of a commercial 85/15 (v/v) sand-peat root zone mix. After applying and raking in a 14-12.3-10 (N-P-K) starter fertilizer at the rate of $49 \mathrm{~kg} \mathrm{Nha}^{-1}$, the area was seed to "SR 1119 " creeping bentgrass (Agrostis stolonifera L.). The green was placed under a grow-in program where irrigation four times daily gradually gave way to daily irrigation at $100 \%$ of estimated ET. Nitrogen fertilizer (urea; 46-0-0) was applied every 2 to 3 weeks to maintain satisfactory turfgrass color, and the putting green was sand top-dressed every 2 to 3 weeks to level the surface and allow for gradual reduction of the mowing height from the initial $1.3 \mathrm{~cm}$ to $0.3 \mathrm{~cm}$ by the end of the establishment year. In October 2003 the green was divided into three blocks, each consisting of three 3.6 by $5.5 \mathrm{~m}$ main plots for an $\mathrm{N}$ rate differential, three 1.2 by $5.5 \mathrm{~m}$ subplots for a $\mathrm{K}$ rate differential, and three 1.8 by $3.6 \mathrm{~m}$ sub-sub plots for a $\mathrm{P}$ rate differential. Urea (46-0-0), ammonium phosphate (11-21-0) and potassium sulfate (0-0-41.5) were applied to establish the nutrient differentials. Rates during the establishment year were 240,265 , and $338 \mathrm{~kg} \mathrm{~N}^{-1}, 43$, 116 , and $146 \mathrm{~kg} \mathrm{Pha}^{-1}$, and 35, 181, and $287 \mathrm{~kg} \mathrm{~K} \mathrm{ha}^{-1}$.

Nutrient rates in the year following putting green the 2003 establishment totaled 112, 254 and $356 \mathrm{~kg} \mathrm{~N} \mathrm{ha}^{-1}, 0,43$ and $86 \mathrm{~kg} \mathrm{Pha}^{-1}$, and 0,53 and $105 \mathrm{~kg} \mathrm{Kha}^{-1}$. Mowing was 5 to 6 days per week at $0.3 \mathrm{~cm}$ and irrigation daily at $80 \%$ ET estimated from on-site weather data. Fungicides were correctively applied as needed to control dollar spot (Sclerotinia homoeocarpa F. Bennett). Clippings collected from $0.4 \mathrm{~m}^{2}$ plot areas in May, July, and October were dried at $65^{\circ} \mathrm{C}$, weighed, cleaned, ground, and analyzed for total $\mathrm{N}, \mathrm{P}$, and $\mathrm{K}$ as described above. Soil samples were removed to a depth 
of $10 \mathrm{~cm}$ from all plots at the times of clipping collection and analyzed for Bray-1 extractable P and K at SPAL.

\subsection{Experiment 2: Effects of Fertilization on Creeping Bent-} grass Growth and Tissue Nutrient Content. This three-year field experiment consisted of four blocks of twelve $1.8 \mathrm{~m} \times$ $2.4 \mathrm{~m}$ plots assigned to a 2-year old "Penncross" creeping bentgrass fairway established on Troxel silt loam (fine silty, mixed, superactive, and mesic Pachric Argiudoll). At the start of the study in 1992, the soil pH was 5.8, and Bray-1 levels of soil $\mathrm{P}$ and $\mathrm{K}$ were $62 \mathrm{mg} \mathrm{kg}^{-1}$ and $180 \mathrm{mg} \mathrm{kg}^{-1}$, respectively. The twelve treatments randomly assigned within each block consisted of a series of nutrient applications. The first series was annual $\mathrm{N}$ rates of 98,195 , or $390 \mathrm{~kg} \mathrm{ha}^{-1}$ applied as a 25-2.2-8.3 (N-P-K) fertilizer with polymer + sulfur-coated urea as the primary $\mathrm{N}$ carrier. The second series of treatments consisted of $\mathrm{N}$ at an annual rate of $195 \mathrm{~kg} \mathrm{ha}^{-1}$ applied with either $21 \mathrm{~kg} \mathrm{Pha}^{-1}, 121 \mathrm{~kg} \mathrm{~K} \mathrm{ha}^{-1}$, or both. The P and $\mathrm{K}$ carriers were triple superphosphate $(0-20-0)$ and potassium sulfate $(0-0-41.5)$. The third series of treatments was $195 \mathrm{~kg} \mathrm{~N}$ $+21 \mathrm{~kg} \mathrm{P}+121 \mathrm{~kg} \mathrm{Kha}^{-1}$ applied with different $\mathrm{N}$ carriers. The carriers were polymer + sulfur-coated urea, ammonium sulfate (21-0-0), and feed grade urea (46-0-0). The final three treatments involved fall and spring applications of elemental $\mathrm{S}$ at $195 \mathrm{~kg} \mathrm{ha}^{-1}$ or ground dolomite limestone (neutralizing index of 90 to 95 ) at $2,440 \mathrm{~kg} \mathrm{ha}^{-1}$ in conjunction with $195 \mathrm{~kg} \mathrm{~N}+21 \mathrm{~kg} \mathrm{P}+121 \mathrm{~kg} \mathrm{Kha}^{-1}$. Polymer + sulfur-coated urea served as the $\mathrm{N}$ carrier when the $\mathrm{S}$ was applied. Urea and ammonium sulfate were the $\mathrm{N}$ carriers for the lime treatments. All fertilizers were applied in four applications equally split between May, July, September, and October of each of the three years the study was conducted.

The creeping bentgrass was maintained as a golf fairway with mowing at $1.3 \mathrm{~cm}$ every Monday, Wednesday, and Friday, and irrigation twice a week at $80 \%$ estimated ET. Fungicides were correctively applied as needed for disease control. Soil samples were annually collected from all plots to a $10 \mathrm{~cm}$ depth in $1.25 \mathrm{~cm}$ increments for measurement of Bray-1 soil test $\mathrm{P}$ and $\mathrm{K}$ at SPAL as described in Experiment 1 . Grass clippings were collected monthly from $0.75 \mathrm{~m}^{2}$ plot areas, oven dried at $65^{\circ} \mathrm{C}$, weighed, and ground for analysis using the same methods described in Experiment 1.

\subsection{Experiment 3: Nitrogen Rates Required for Maximum} Turfgrass Biomass Production. Two trials were conducted, the first on a 4-year old stand of Kentucky bluegrass (Poa pratensis L.) and the second on a 3-year old stand of "Penncross" creeping bentgrass (Agrostis stolonifera L.) maintained as a golf course fairway. Soil on both sites was Troxel silt loam (fine silty, mixed, superactive, mesic Pachic Argiudoll) having a pH of 6.8 and Bray-1 soil tests of 60 to $62 \mathrm{mg} \mathrm{P} \mathrm{kg}^{-1}$ and 120 to $140 \mathrm{mg} \mathrm{K} \mathrm{kg}^{-1}$. Annual $\mathrm{N}$ rates for the Kentucky bluegrass were 0, 98, 195, 293, 390, 488, 585, and $780 \mathrm{~kg}^{-1}$ split into four equal applications made in May, July, August, and September to plots measuring 2.5 by $7.6 \mathrm{~m}$. The $\mathrm{N}$ was applied as a 25-2.2-8.3 (N-P-K) grade fertilizer containing polymer + sulfur-coated urea as the $\mathrm{N}$ carrier. The site was irrigated twice weekly at $80 \%$ ET estimated from weather station data. Mowing was every 3 to 4 days at $6.4 \mathrm{~cm}$ and clippings removed. Clippings were collected from $0.8 \mathrm{~m}^{2}$ areas of each plot, dried at $65^{\circ} \mathrm{C}$, and weighed. Nitrogen in the form of feed grade urea (46-0-0) was applied to 0.6 by $3.6 \mathrm{~m}$ plots on the creeping bentgrass fairway at rates of $0,100,214,388,684,858$, and $1,032 \mathrm{~kg} \mathrm{ha}^{-1}$ split into 6 equally sized applications spaced evenly throughout the growing season. Irrigation was thrice weekly at $80 \%$ estimated ET. Mowing with clipping removal was at a height of $1.3 \mathrm{~cm}$ every other day. Clippings were collected at each mowing from $3.2 \mathrm{~m}^{2}$ plot areas, dried at $65^{\circ} \mathrm{C}$, and weighed.

\subsection{Experiment 4: Late-Season Creeping Bentgrass Responses} to Trinexapac-Ethyl Applications. After judiciously applying $\mathrm{P}$ and $\mathrm{K}$ to the putting green employed in the soil test calibration study (Experiment 1 ) to adjust soil $\mathrm{P}$ and $\mathrm{K}$ to uniformly high levels, the green was divided into three blocks, each comprised of ten 2.4 by $3.6 \mathrm{~m}$ plots. In September 2005, treatments consisting of trinexapac-ethyl (TE) at rates of 0 , $0.016,0.032$, and $0.064 \mathrm{~mL} / \mathrm{m}^{2}$, each at intervals of 1,2 , and 3 weeks, were randomly assigned to the plots. Trinexapac-ethyl application was with a $\mathrm{CO}_{2}$-powered backpack sprayer calibrated to deliver $9.3 \mathrm{~mL} \mathrm{~m}^{-2}$. Clippings were collected weekly from $1.4 \mathrm{~m}^{2}$ plot areas, dried at $65^{\circ} \mathrm{C}$, and weighed. The study was continued for a period of 7 weeks during September and October 2005. Select samples from the last two sets of clippings were bulked, ground, and analyzed for total nutrient content using the same methods as in Experiment 1.

2.5. Statistical Methods. Data for Experiments 1-4 were analyzed using regression analysis in the JMP statistical software package (Version 6.0; SAS Institute, Cary, NC). Data from Experiment 2 were also analyzed using analysis of variance followed by Duncan's Least Statistical Difference (LSD) to separate treatment means at the alpha $=0.05$ level with the CoStat statistical software package (Version 6.4; CoHort Software, Monterey, CA, USA).

\section{Results and Discussion}

3.1. Evidence for Nutrient Demand. If plant growth rate regulates nutrient demand and is the principal driving force for nutrient uptake [1-4], then nutrient uptake should be strongly dependent on growth rate. This was evident in data from Experiment 1, where regressions of nutrient uptake on creeping bentgrass growth rates yielded $R^{2}$ values ranging from 0.910 to 0.982 for N, P, and K (Figure 1) and 0.884 to 0.932 for $\mathrm{Ca}, \mathrm{Mg}$ and S (Figure 2).

Another characteristic of plant nutrient demand is that once the external nutrient supply attains the level where demand is satisfied, tissue nutrient concentrations plateau, exhibiting little or no change with further increases in nutrient supply [21]. This pattern of turfgrass response to increasing nutrient supplies has been observed by other researchers and occurs regardless of whether the turf property measured is turfgrass quality [34], shoot counts, thatch thickness, relative yield, quality, tissue nutrient content, or root weight $[23,35]$. 


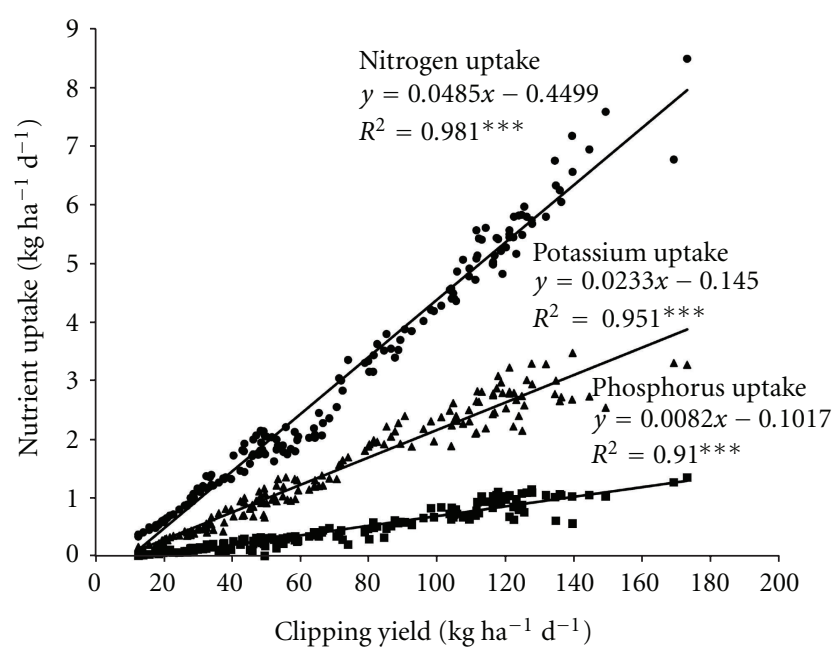

Figure 1: Uptake of N, P, and K uptake as affected by clipping yield for a creeping bentgrass (A. stolonifera) putting green (Experiment 1). All slopes were statistically significant at $P<0.001$ as indicated by $* * *$.

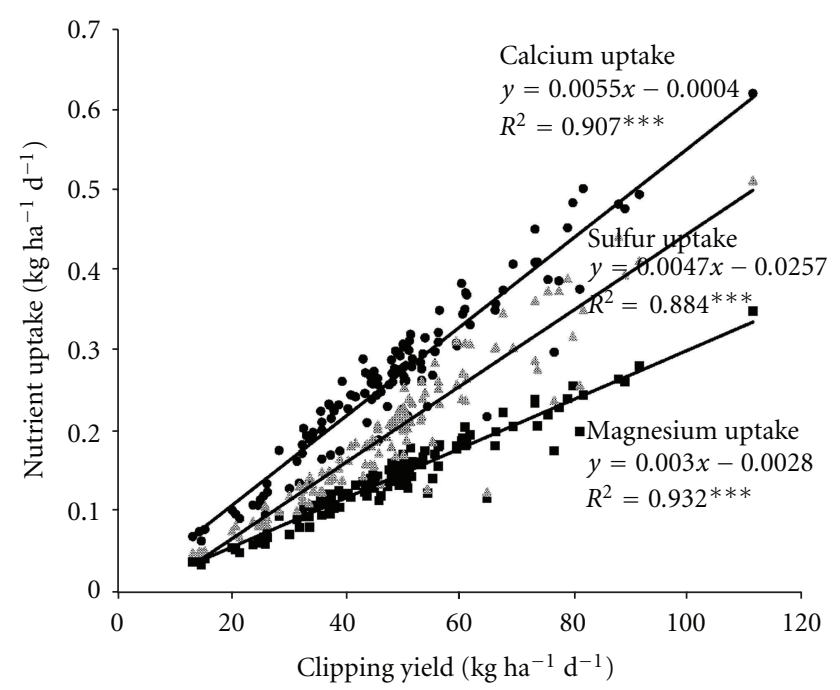

Figure 2: Daily uptake of $\mathrm{Ca}, \mathrm{Mg}$, and $\mathrm{S}$ as affected by clipping yield for a creeping bentgrass (Agrostis stolonifera L.) putting green grown on a sand-matrix root zone (Experiment 1). All regression models were statistically significant at $P<0.001$ as indicated by $* * *$.

Clipping nutrient content plateaued in data collected from the 419 Wisconsin putting greens (Experiment 1). As shown in Figure 3, there was no significant increase $(P=$ $0.62)$ in the mean tissue $\mathrm{P}$ content as Bray-1 $\mathrm{P}$ increased from 1.8 to $200 \mathrm{mg} \mathrm{kg}^{-1}$. This suggests that at the rates of $\mathrm{N}$ being applied plant demand was being met at the lowest P levels found in the study. For K (Figure 3), there was a slight increase in plant $\mathrm{K}$ across all levels of increasing soil $\mathrm{K}$. This may indicate that, in addition to growth-induced plant demand, $\mathrm{K}$ uptake is also influenced to some degree by its prominent role in osmotic regulation [20].

Lack of turfgrass response to increased nutrient supplies when demand is already being satisfied was also evidenced

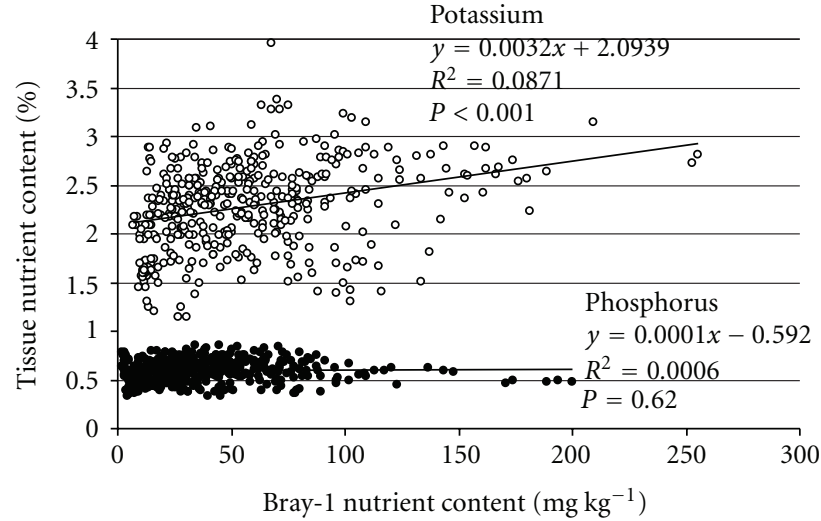

FIGURE 3: Relationship between Bray1-extractable soil P or K levels and tissue $\mathrm{P}$ or $\mathrm{K}$ content of cool season turfgrass species collected from 419 golf greens in Wisconsin (Experiment 1).

TABle 1: Influences of $\mathrm{N}, \mathrm{P}$, and $\mathrm{K}$ applications on creeping bentgrass clipping $\mathrm{N}, \mathrm{P}$, and $\mathrm{K}$ content for a site high in soil $\mathrm{P}$ and $\mathrm{K}$ (Experiment 2).

\begin{tabular}{|c|c|c|c|}
\hline Nutrients applied & \multicolumn{3}{|c|}{ Turfgrass Clipping Nutrient Content } \\
\hline $\mathrm{N}-\mathrm{P}-\mathrm{K}$ & $\mathrm{N}$ & $\mathrm{P}$ & $\mathrm{K}$ \\
\hline $\mathrm{Kg} \mathrm{ha}^{-1}$ & \multicolumn{3}{|c|}{$\mathrm{g} \mathrm{kg}^{-1}$} \\
\hline $195-0-0$ & 42.6 & 4.4 & 25.4 \\
\hline $195-21-0$ & 43.3 & 4.4 & 26.2 \\
\hline $195-0-121$ & 42.3 & 4.2 & 25.6 \\
\hline $195-21-121$ & 43.3 & 4.3 & 26.4 \\
\hline Duncan's LSD $\mathrm{LD}_{0.05}$ & NS & NS & NS \\
\hline
\end{tabular}

in Experiment 2 conducted on a soil whose soil test $\mathrm{P}$ and $\mathrm{K}$ levels were approximately three times those considered to be optimum by University of Wisconsin-Extension recommendations [36]. Under these circumstances application of fertilizer $\mathrm{P}$ and $\mathrm{K}$ did not significantly alter clipping $\mathrm{P}$ and $\mathrm{K}$ content (Table 1). However, application of $\mathrm{N}$ alone to stimulate growth increased clipping $\mathrm{N}, \mathrm{P}$, and $\mathrm{K}$ content and rates of decline in soil test $\mathrm{P}$ and $\mathrm{K}$ paralleled to the $\mathrm{N}$ application rate (Table 2). This observation has the ironic implication that when soil supply of $\mathrm{K}$ is high and a turf manager seeks to increase tissue $\mathrm{K}$ content to enhance drought resistance, increase heat and traffic tolerance, or reduce winter injury [37], the most effective approach may be to apply N.

These experimental results provide three lines of evidence that turfgrass absorbs nutrients according to demand that is governed by growth rate. Growth rate typically accounts for more than $90 \%$ of the variation in nutrient uptake, once nutrient demand is satisfied, further increases in external supply have little influence on tissue content, and tissue nutrient content can vary widely at a given external supply due to differences in growth driven demand. The issue then becomes that of determining what growth factor or factors most commonly govern turfgrass growth.

3.2. Regulation of Turfgrass Nutrient Demand. In 2003, Bowman surmised that today's fertility programs are purposely 
TABLE 2: Influence of annual $\mathrm{N}$ rate on creeping bentgrass clipping $\mathrm{N}, \mathrm{P}$, and $\mathrm{K}$ content and reductions in soil test $\mathrm{P}$ and $\mathrm{K}$ for a site high in soil $\mathrm{P}$ and $\mathrm{K}$ (Experiment 2).

\begin{tabular}{|c|c|c|c|c|c|}
\hline \multirow{3}{*}{$\begin{array}{l}\text { Annual } \mathrm{N} \text { rate } \\
\mathrm{kg} \mathrm{ha}^{-1}\end{array}$} & \multicolumn{3}{|c|}{ Turfgrass clipping nutrient content } & \multicolumn{2}{|c|}{ Reductions in Bray-1 soil test level over three years } \\
\hline & $\mathrm{N}$ & $\mathrm{P}$ & $\mathrm{K}$ & $\mathrm{P}$ & $\mathrm{K}$ \\
\hline & & $\mathrm{g} \mathrm{kg}^{-1}$ & & \multicolumn{2}{|c|}{$\mathrm{mg} \mathrm{kg}^{-1}$} \\
\hline 98 & 37.9 & 4.2 & 24.0 & 6 & 25 \\
\hline 195 & 42.6 & 4.4 & 26.4 & 10 & 37 \\
\hline 390 & 52.3 & 4.8 & 29.4 & 17 & 57 \\
\hline Duncan's LSD ${ }_{0.05}$ & 1.4 & 0.3 & 0.8 & 3 & 11 \\
\hline
\end{tabular}

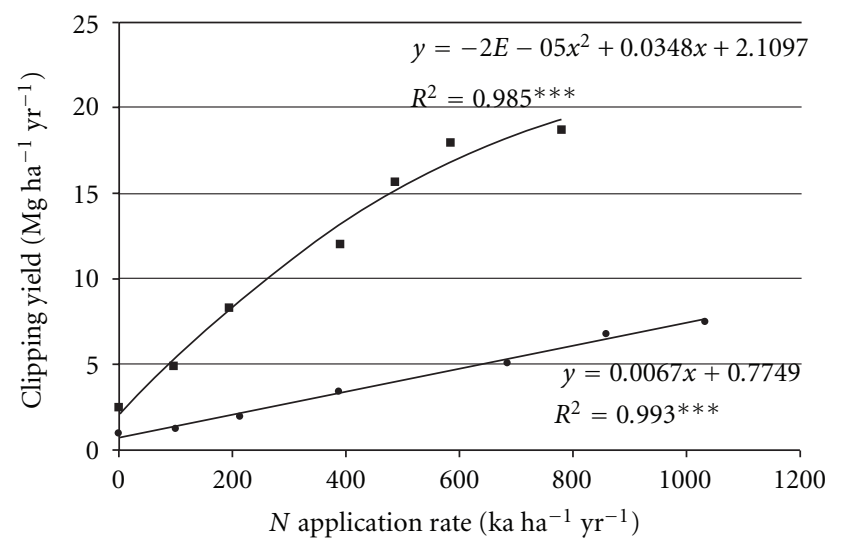

- Creeping bentgrass

- Kentucky bluegrass

FIgURE 4: Clipping production of a creeping bentgrass (Agrostis stolonifera) fairway and a Kentucky bluegrass (Poa pratensis) lawn as affected by annual $\mathrm{N}$ fertilization amount (Experiment 1 ). Both regression models were statistically significant at $P<0.001$ as indicated by $* * *$.

designed to moderate effects on turfgrass growth, the results being suboptimal growth rates and $\mathrm{N}$ deficiency as a normal condition. If true, then $\mathrm{N}$ applied at conventional rates should always induce rapid growth responses that remain well within the linear range of biomass production. Some evidence for this comes from the work of Goatly et al. [38]. Three rates of late season $\mathrm{N}$ applied to bermudagrass linearly increased clipping production and leaf $\mathrm{N}, \mathrm{P}$, and $\mathrm{K}$ content. Regression of their clipping N, P, and K content on N application rate yields $R^{2}$ values of 0.860 to 0.961 , indicating operation of growth-driven nutrient demand.

Data from our Experiment 3 confirmed that, at conventional $\mathrm{N}$ rates, turfgrass growth is far from optimal. The rate of $\mathrm{N}$ required for maximum Kentucky bluegrass annual clipping production was in excess of $700 \mathrm{~kg} \mathrm{ha}^{-1}$ and in excess of $1000 \mathrm{~kg} \mathrm{ha}^{-1} \mathrm{Nyr}^{-1}$ for a creeping bentgrass fairway (Figure 4). Rates of $\mathrm{N}$ recommended for Kentucky bluegrass lawns in the upper Midwest range from 150 to $250 \mathrm{~kg} \mathrm{ha}^{-1} \mathrm{yr}^{-1}$. Annual $\mathrm{N}$ rates for bentgrass fairways range from 150 to $300 \mathrm{~kg} \mathrm{ha}^{-1} \mathrm{yr}^{-1}$. According to Figure 4, these $\mathrm{N}$ rates are but $15-30 \%$ of the quantities required for maximum clipping production. This supports the contention of Bowman [39] that under normal fertilization practices turfgrass is continuously $\mathrm{N}$ deficient from the perspective of clipping

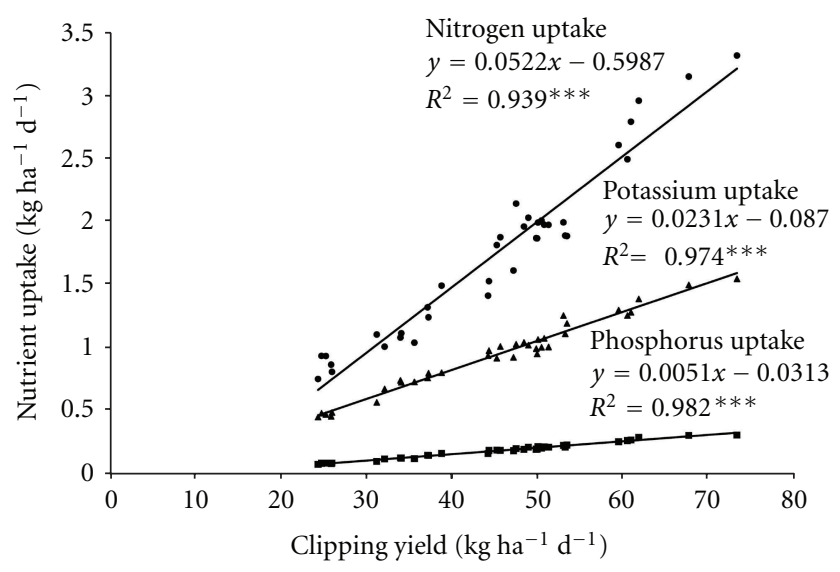

FIGURE 5: Daily uptake of N, P, and $\mathrm{K}$ as affected by clipping yield for a creeping bentgrass (Agrostis stolonifera L.) putting green grown on a sand-matrix root zone (Experiment 1). All regression models were statistically significant at $P<0.001$ as indicated by $* * *$.

production, setting up $\mathrm{N}$ supply as a prime factor controlling turfgrass growth-driven nutrient demand.

Another widespread cultural practice anticipated to have a controlling influence on turfgrass nutrient demand is application of plant growth regulators. In our Experiment 4, late season application of trinexapac-ethyl (TE) at three rates and three intervals resulted in 3 to $64 \%$ reductions in creeping bentgrass clipping production at a single $\mathrm{N}$ rate. Under these circumstances, clipping yields accounted for 94 to $99 \%$ of the variation in uptake of not only N, P, and K (Figure 5), but $\mathrm{Ca}, \mathrm{Mg}$, and $\mathrm{S}$ as well (not shown).

Data presented by McCullough et al. [40] serve to further examine the effects of both $\mathrm{N}$ rate and TE on turfgrass growth and nutrient uptake relationships. They applied four rates of $\mathrm{N}$ with and without $\mathrm{TE}$ to a bermudagrass putting green over two years. The TE reduced clipping production by a nearly constant $67 \%$ over the four $\mathrm{N}$ rates but did not alter the rate of $\mathrm{N}$ required to maintain acceptable color at different periods of time. Nutrient removal by the clippings when TE was applied was decreased by $70 \%$, almost the same as the average percent reduction in clipping production. According to their data, clipping production accounted for 83 to $99 \%$ of the variation in clipping removals of $\mathrm{N}, \mathrm{P}, \mathrm{K}$, $\mathrm{Ca}, \mathrm{Mg}, \mathrm{S}, \mathrm{Cu}, \mathrm{Fe}, \mathrm{Mn}$, and $\mathrm{Zn}$.

The strong influences of $\mathrm{N}$ rate and TE on turfgrass growth do not preclude the possibility that environmental 


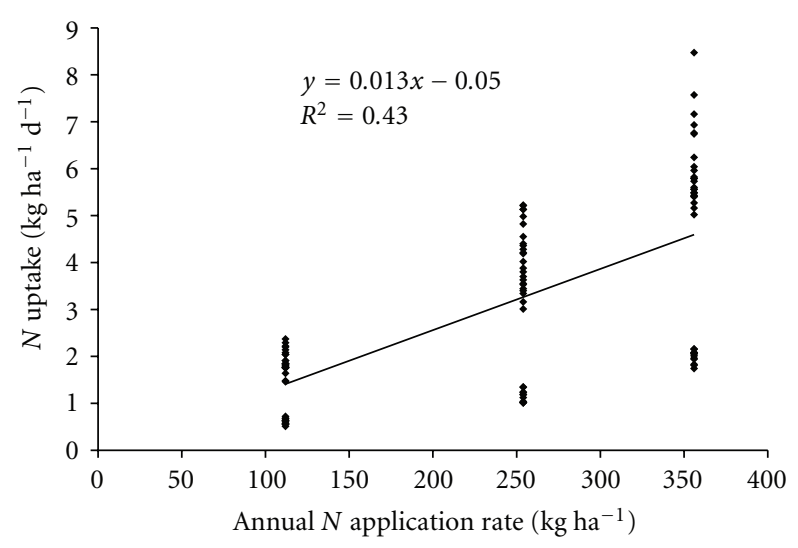

(a)

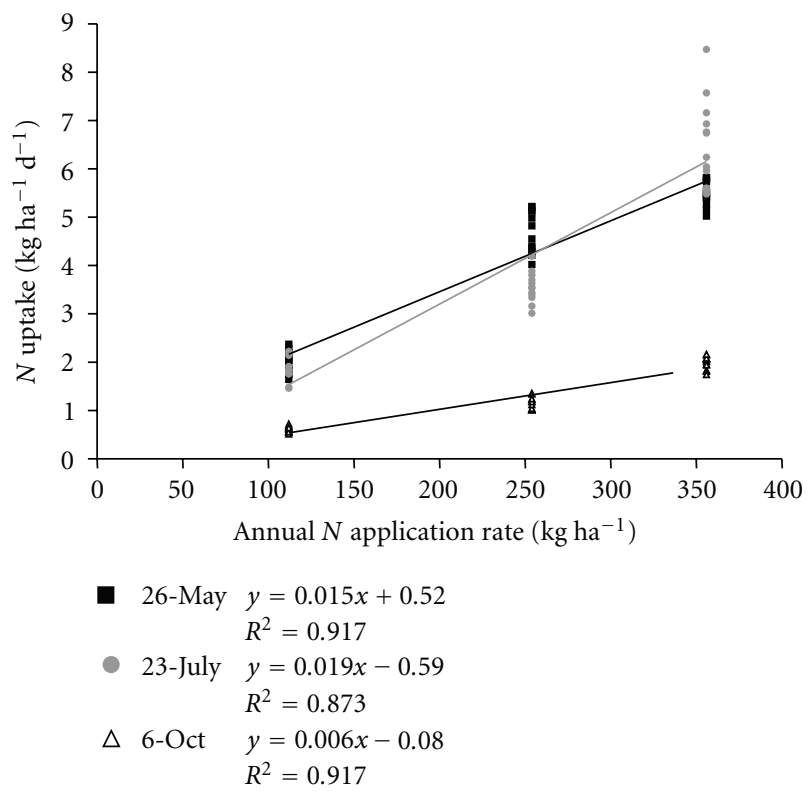

(b)

FIGURE 6: Relationship between $\mathrm{N}$ application rate and $\mathrm{N}$ uptake for a creeping bentgrass putting green in July and October. Differing environmental conditions lead to different relationships between application rate and uptake as shown by linear regression with combined data (a) and separate regression lines (b) (Experiment 2). All regression models (both a and $b$ ) were statistically significant $(P<0.001)$.

conditions may also have notable effects on turfgrass nutrient demand. In our Experiment 2, three $\mathrm{N}$ rates were imposed on a creeping bentgrass fairway over three years and clippings collected three times each year for weight determination and analysis. Across the three seasons $\mathrm{N}$ rate accounted for only $43 \%$ of the variation in $\mathrm{N}$ uptake (Figure 6(a)). However, coefficients of determination $\left(R^{2}\right)$ for the individual months (time of year) ranged from 0.87 to 0.92 (Figure 6(b)). During May and July $\mathrm{N}$ uptake increased from 0.015 to $0.019 \mathrm{~kg} \mathrm{ha}^{-1}$ $\mathrm{da}^{-1}$ per $\mathrm{kg} \mathrm{ha}^{-1}$ of $\mathrm{N}$ applied. In October, when declining air temperatures suppressed turfgrass growth, $\mathrm{N}$ uptake increased only $0.006 \mathrm{~kg} \mathrm{ha}^{-1}$ for each $\mathrm{kg} \mathrm{ha}^{-1}$ of $\mathrm{N}$ applied. But at all times $\mathrm{N}$ uptake increased linearly with $\mathrm{N}$ rate, as did uptakes of P and $\mathrm{K}$ (data not shown). This is the same circumstance that arises when a growth regulator is applied. The degree of turfgrass growth suppression is constant across $\mathrm{N}$ rates, maintaining linear increases in nutrient uptakes associated with $\mathrm{N}$-induced growth and nutrient demand.

The data presented here provide convincing evidence that $\mathrm{N}$ supply is a primary factor governing turfgrass nutrient demand. Similarly, application of a plant growth regulator changes demand in accord with the degree of suppression of turfgrass growth at any given level of $\mathrm{N}$ application. While the rate of change in demand per unit of $\mathrm{N}$ applied is reduced, the strength of the relationship between nutrient uptake and $\mathrm{N}$ supply remains very high. The same circumstance appears to arise in the presence of growth-limiting environmental stresses such as suboptimal temperature.

3.3. Consequences of Turfgrass Nutrient Demand. There are two prominent consequences of nutrient demand regulation of nutrient uptake on turfgrass responses to increasing soil supplies of nutrients. One is wide variation in turfgrass response at specified soil test values of $\mathrm{P}$ and $\mathrm{K}$. The other is a leveling-off of nutrient uptake and tissue nutrient content when nutrient supply exceeds demand. Research conducted by Johnson et al. [34], Guillard and Dest [35], and Woods et al. [23] and data from our work (Figure 3) clearly show wide ranges in tissue nutrient content at given soil test levels of nutrients. Irrespective of the turfgrass response parameter used to develop soil test calibrations, these studies encountered wide ranges in turfgrass response at any particular level of soil test P or K. The data presented by Johnson et al. [34] show that at any given level of soil test $\mathrm{P}$ turfgrass quality ratings varied by as much as 5 units on a scale of 1 to 9 . Woods et al. [23] observed that creeping bentgrass tissue $\mathrm{K}$ content varied as much as $450 \mathrm{mmol} \mathrm{kg}^{-1}$ at a given level of soil test $\mathrm{K}$ for any and all methods used to estimate soil $\mathrm{K}$.

We surmised that the wide variation in turfgrass tissue contents of nutrients at given soil test is a reflection of variation in nutrient demand resulting from differences in $\mathrm{N}$ nutrition. Evidence for this was sought by sorting the data from Experiment 1 into different ranges in tissue $\mathrm{N}$ and calculating the mean tissue $\mathrm{P}$ or $\mathrm{K}$ content for each $\mathrm{N}$ range. Plots of these tissue $\mathrm{P}$ and $\mathrm{K}$ contents versus clipping $\mathrm{N}$ range revealed highly significant linear relationships with $R^{2}$ values, respectively, of 0.934 and 0.986 for $\mathrm{P}$ and $\mathrm{K}$ (Figure 7). Recalling that the main source of the data set is paired clipping and soil samples collected from 419 Wisconsin putting greens, the implication is that such relationships hold over what may be assumed to be substantial differences in weather, cultural practices, and turfgrass species and cultivars.

The second consequence of demand-driven nutrient uptake across increasing soil supplies of nutrients is that once demand is satisfied at the growth rate sustained by the amount of $\mathrm{N}$ being applied, there is little or no additional turfgrass response when nutrient supplies exceed those required to satisfy demand [21]. This is evident in Figure 3 as well as in the data presented by other researchers $[23,34,35]$. The responses presumably plateau once physiological requirements for the nutrients are satisfied at the prevailing growth 


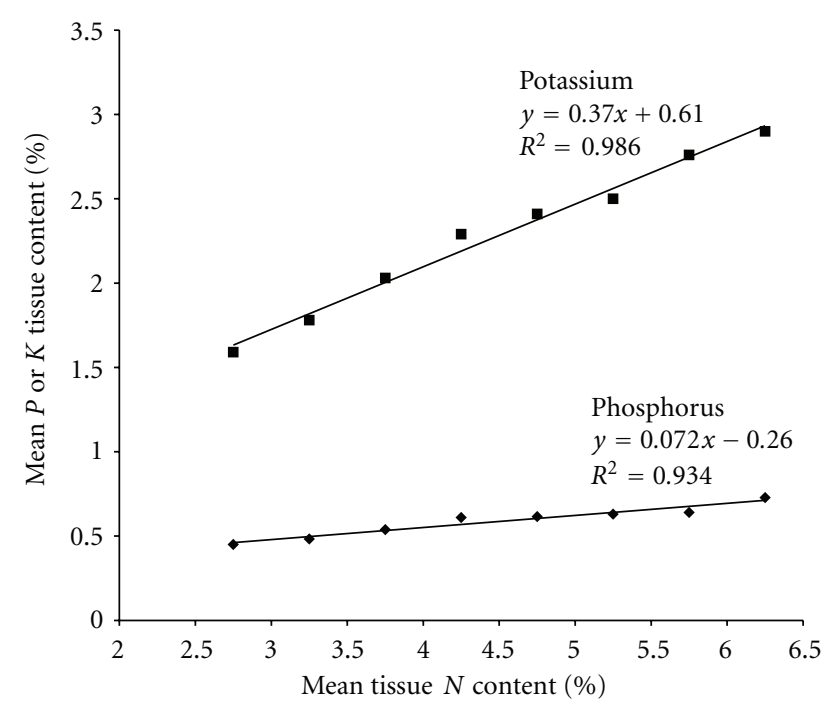

Figure 7: Phosphorus and $\mathrm{K}$ content as a function of tissue $\mathrm{N}$ content for 419 tissue samples collected from putting greens around the state. Each data point represents a mean of all points within a particular $\mathrm{N}$ range. For example the $4.25 \% \mathrm{~N}$ data points for $\mathrm{P}$ and $\mathrm{K}$ are the averages for all tissue samples with an $\mathrm{N}$ content between $4.0 \%$ and $4.5 \%(n=75)$. Both regression models were statistically significant $(P<0.001)$.

rates. This may well explain why there is no luxury uptake of $\mathrm{K}$ by turfgrass [29] and that uptakes of $\mathrm{K}, \mathrm{Ca}$, and $\mathrm{Mg}$ reflect their physiological requirements rather than their ratios on soil cation exchange sites [27].

Turfgrass clipping nutrient content has been reported to change significantly over the course of a growing season even when nutrient supply is more than adequate. Davis [41] noted that Kentucky bluegrass clipping $\mathrm{K}$ content varied more with time of sampling than rate of $\mathrm{K}$ application. Waddington et al. [42] recorded seasonal variations of 2.5 to $5.6 \mathrm{~g} \mathrm{P} \mathrm{kg}^{-1}$ and 15 to $25 \mathrm{mg} \mathrm{K} \mathrm{kg}^{-1}$ in creeping bentgrass. Comparable results have been reported by Hall and Miller [43] for Kentucky bluegrass. No attempts have been made to explain these seasonal changes in tissue $\mathrm{P}$ and $\mathrm{K}$ content and have been cited as a reason why tissue nutrient content is not an appropriate plant parameter for calibrating soil tests for turfgrass [37].

Growth rate, the generator of nutrient demand, was investigated as the prime factor leading to time of season variations in turfgrass tissue nutrient $\mathrm{P}$ and $\mathrm{K}$ content. Analysis of data from Waddington et al. [42] revealed that their seasonally dependent creeping bentgrass clipping $\mathrm{P}$ content was strongly related to clipping $\mathrm{N}$ content $\left(R^{2}=\right.$ 0.956). The relationship of tissue $\mathrm{K}$ to $\mathrm{N}$ was not as strong $\left(R^{2}=0.540\right)$. However, their soil test $\mathrm{K}$ levels were well above what recent research indicates as being optimum for sand putting greens and were in the range where creeping bentgrass response plateaus [23]. In our Experiment 2 clippings were collected on five dates in a single season from a creeping bentgrass fairway established on a silt loam soil and subjected to several different fertilizer treatments. Time of season variations in tissue nutrient contents varied from 3.1 to $4.9 \mathrm{~g} \mathrm{~kg}^{-1}$ for $\mathrm{P}$ and 24 to $25.9 \mathrm{~g} \mathrm{~kg}^{-1}$ for $\mathrm{K}$. These clipping $\mathrm{P}$ and $\mathrm{K}$ contents were found to be highly correlated with clipping $\mathrm{N}\left(R^{2}=0.986\right.$ for $\mathrm{P}, 0.907$ for $\left.\mathrm{K}\right)$ and $\mathrm{N}$ uptake accounted for 98 to 99 percent of the seasonal variations in $\mathrm{P}$ and $\mathrm{K}$ uptakes. This is evidence that seasonal variations in turfgrass tissue nutrient content result from time-of-year variations in growth rate-induced nutrient demand.

Considerable variability in nutrient use efficiency has been observed for different turfgrass species and their cultivars [24-27], raising the specter that choice of species or cultivar can significantly alter fertilizer requirements. The assumption has been that genetics somehow gives rise to turfgrass species and cultivar differences in nutrient use efficiencies. Sartain and Dudeck [27] found N use efficiencies of $2.38 \mathrm{~g}$ dry matter $(\mathrm{DM}) \mathrm{mg}^{-1} \mathrm{~N}$ taken up by bermudagrass, but only $0.133 \mathrm{~g} \mathrm{DM} \mathrm{mg}^{-1} \mathrm{~N}$ for perennial ryegrass. When the growth rates of the two species are combined into a single data set, differences in growth rates explain 97.5 to $99.0 \%$ of the species differences in $\mathrm{N}, \mathrm{P}$, and $\mathrm{K}$ uptake. The data of Mehall et al. [24] for 15 field grown Kentucky bluegrass cultivars similarly show that differences in cultivar growth rates accounted for 73 to $84 \%$ of the differences in tissue P and K content. Menzel and Broomhall [26], who grew eight tropical turfgrass species under different fertility regimes, observed significant differences in growth responses and nutrient uptake. Analysis of their data shows that species differences in clipping production could account for 76 to $98 \%$ of the variations in $\mathrm{N}, \mathrm{P}$, and $\mathrm{K}$ uptakes.

Liu et al. [25] reported significant differences in growth rates and $\mathrm{K}$ use efficiencies for six cultivars each of Kentucky bluegrass, perennial ryegrass, and tall fescue. They attributed differences in potassium use efficiencies of the various species and cultivars to genetically linked differences in $\mathrm{K}$ uptake kinetics. But inspection of their data reveals that, irrespective of species or cultivar, growth rates could account for over $94 \%$ of the observed variations in $\mathrm{K}$ uptake (Figure 8). This observation is consistent with reports that the nutrient uptake kinetic parameters $K_{m}$ and $C_{m}$, when measured for whole plants, are not genetic characteristics but vary due to changes in growth-related nutrient demand [44-46]. This, plus the data discussed above, serves as evidence that turfgrass species and cultivar differences in nutrient use efficiencies are largely manifestations of differences in genetic predispositions for biomass production in a given environment.

\section{Conclusions}

Three prominent characteristics of plant growth-driven nutrient demand are: (1) nutrient uptake and tissue content are more closely related to growth rates than external nutrient supply; (2) nutrient uptake at a given level of external supply varies substantially in response to variable nutrient demand; (3) tissue nutrient content tends to remain constant once external nutrient supplies allow plants to satisfy their demand. Our research (Figures 1, 2, and 3) confirmed that turfgrass exhibits all of these characteristics.

Nitrogen application at conventional rates of 150 $300 \mathrm{~kg} \mathrm{ha}^{-1} \mathrm{yr}^{-1}$ on a creeping bentgrass fairway and 146 to 


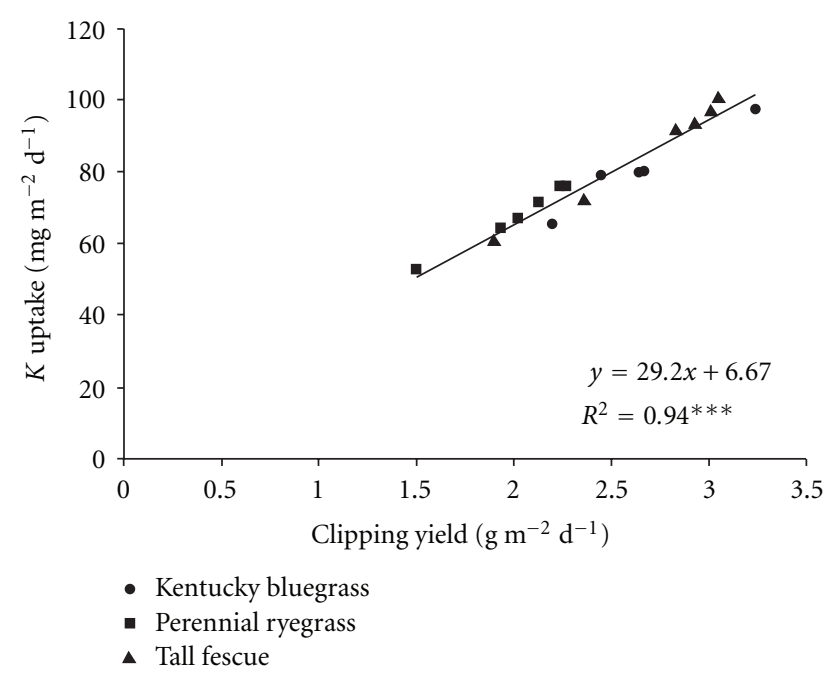

FIGURE 8: Alternative analysis of data presented by Liu et al. [25] who concluded that differences in $\mathrm{K}$ uptake among 3 species of grasses and 6 cultivars of each grass were due to genetically linked differences in $\mathrm{K}$ uptake kinetics. However, reanalysis of the data (above) suggests that differences in growth rate (also genetically controlled) account for $94 \%$ of the variation in $\mathrm{K}$ uptake.

$195 \mathrm{~kg} \mathrm{ha}^{-1}$ season $^{-1}$ on a Kentucky bluegrass lawn resulted in clipping yields that were 15 to $35 \%$ of the maximums. This distinguishes turfgrass from most field crops where $\mathrm{N}$ rates are geared toward optimum biomass production. In turfgrass the suboptimal $\mathrm{N}$ supply is a major determinant of turfgrass growth rate-driven nutrient demand. Evidence for this was the strong dependencies of uptakes of $\mathrm{N}, \mathrm{P}, \mathrm{K}, \mathrm{Ca}, \mathrm{Mg}$, and $\mathrm{S}$ on turfgrass growth and tissue $\mathrm{N}$ uptake, both indicators of nutrient demand. Application of a PGR or environmental stresses associated with time of season modified turfgrass response to increasing $\mathrm{N}$ rates but did not alter the relationships of growth rate or tissue $\mathrm{N}$ to tissue content of other nutrients.

The prominence of nitrogen-driven nutrient demand in turfgrass may account for the fact that turfgrass does not accumulate what might be considered luxury amounts of $\mathrm{K}$ and the lack of a relationship between plant $\mathrm{K}, \mathrm{Ca}$, and $\mathrm{Mg}$ content and the ratios of the cations on the soil exchange complex. These observations support the contention that tissue nitrogen content may need to be considered for establishment of critical soil test values for turfgrass.

\section{References}

[1] P. J. Woodhouse, A. Wild, and C. R. Clement, "Rate of uptake of potassium by three crop species in relation to growth," Journal of Experimental Botany, vol. 29, no. 4, pp. 885-894, 1978.

[2] C. R. Clement, L. H. P. Jones, and M. J. Hopper, "Uptake of nitrogen from flowing nutrient solution: effect of terminated and intermittent nitrate supplies," in Nitrogen Accumulation of Plants, E. T. Hewitt and C. V. Cutting, Eds., Long Ashton Symposium 6, pp. 123-133, Academic Press, London, UK, 1979.
[3] T. Ingestad, "Relative addition rate and external concentration; driving variables used in plant nutrition research," Plant, Cell \& Environment, vol. 5, pp. 443-453, 1982.

[4] A. D. M. Glass, "Nutrient absorption by plant roots: regulation of uptake to match demand," in Plant Roots. The Hidden Half, Y. Wwaisel, A. Waisel, and U. Kafkafi, Eds., pp. 571-586, Marcel Dekker, New York, NY, USA, 2002.

[5] P. H. Nye and P. B. Tinker, Solute Movement in the Soil-Plant System, Studies in Ecology Vol. 4, University of California Press, Berkely, Calif, USA, 1977.

[6] R. F. Williams, "The effects of phosphorus supply on the rates of intake of phosphorus and nitrogen and upon certain aspects of phosphorus metabolism in gramineous plants," Australian Journal of Soil Research, vol. 1, pp. 333-361, 1948.

[7] D. T. Clarkson, "Phosphorus supply and growth in species of Agrostis L.," Journal of Ecology, vol. 55, pp. 111-118, 1967.

[8] J. F. Loneraga and C. J. Asher, "Response of plants to phosphate concentration in solution culture: II. Rate of phosphorus absorption in its relation to growth," Soil Science, vol. 103, pp. 311-318, 1967.

[9] H. Nassery, "Phosphate absorption by plants from habitats of different phosphate status. III. Phosphate fractions in the roots of intact plants," New Phytologist, vol. 70, pp. 949-951, 1971.

[10] M. G. Pitman, "Uptake and transport of ions in barley seedlings. III. Correlation between transport to the shoot and relative growth rate," Australian Journal of Biological Sciences, vol. 25, pp. 905-919, 1972.

[11] R. E. White, "Studies on mineral ion absorption by plantsI. The absortion and utilization of phosphate by Stylosanthes humilis, Phaseolus atropurpureus and Desmodium intortum," Plant and Soil, vol. 36, no. 1, pp. 427-447, 1972.

[12] R. E. White, "Studies on mineral ion absorption by plantsII. The interaction between metabolic activity and the rate of phosphorus uptake," Plant and Soil, vol. 38, no. 3, pp. 509-523, 1973.

[13] H. D. Cooper and D. T. Clarkson, "Cycling of amino-nitrogen and other nutrients between shoots and roots in cerealsa possible mechanism integrating shoot and root in the regulation of nutrient uptake," Journal of Experimental Botany, vol. 40, pp. 753-762, 1989.

[14] H. Marschner, E. A. Kirkby, and C. Engels, "Importance of cycling and recycling of mineral nutrients within plants for growth and development," Botanica Acta, vol. 110, no. 4, pp. 265-273, 1997.

[15] J. Imsande and B. Touraine, "N demand and the regulation of nitrate uptake," Plant Physiology, vol. 105, no. 1, pp. 3-7, 1994.

[16] A. G. Lappartient, J. J. Vidmar, T. Leustek, A. D. M. Glass, and B. Touraine, "Inter-organ signaling in plants: regulation of ATP sulfurylase and sulfate transporter genes expression in roots mediated by phloem-translocated compound," Plant Journal, vol. 18, no. 1, pp. 89-95, 1999.

[17] M. G. Palmgren, "Plant plasma membrane $\mathrm{H}^{+}$-ATPases: powerhouses for nutrient uptake," Annual Review of Plant Bio$\log y$, vol. 52, pp. 817-845, 2001.

[18] M. Schumacher and J. P. Adelman, "Ion channels: an open and shut case," Nature, vol. 417, no. 6888, pp. 501-502, 2002.

[19] A. A. Steiner, "The selective capacity of plants for ions and its importance for the composition and treatment of nutrient solution," in Proceedings of the 5th International Congress on Soilless Culture (ISOSC '80), pp. 83-95, May 1980.

[20] H. Marschner, Mineral Nutrition of Higher Plants, Academic Press, New York, NY, USA, 1995. 
[21] P. Nissen, "Nutrient uptake by plants: effect of external ion concentration," in Symposium on Nutrition, Growing Techniques and Plant Substrates, H. R. Gisholt, Ed., pp. 21-28, Acta Horticulturae (ISHS), Leuven, Belgium, 1986.

[22] A. Scaife, "Fall in nutrient demand per unit root length during the linear phase of plant growth," Plant and Soil, vol. 164, no. 2, pp. 315-317, 1994.

[23] M. S. Woods, Q. M. Ketterings, F. S. Rossi, and A. M. Petrovic, "Potassium availability indices and turfgrass performance in a calcareous sand putting green," Crop Science, vol. 46, no. 1, pp. 381-389, 2006.

[24] B. J. Mehall, R. J. Hull, and C. R. Skogley, "Cultivar variation in Kentucky bluegrass: P-nutritional and K-nutritional factors," Agronomy Journal, vol. 75, pp. 767-771, 1983.

[25] H. Liu, R. I. Hull, and D. T. Duff, "Comparing cultivars of three cool-season turf-grasses for potassium uptake kinetics and potassium recovery in the field," Journal of Plant Nutrition, vol. 18, no. 3, pp. 467-485, 1995.

[26] C. M. Menzel and P. Broomhall, "Nutrient uptake in tropical turfgrasses growing in winter in southern Queensland," Australian Journal of Experimental Agriculture, vol. 46, no. 9, pp. 1217-1224, 2006.

[27] J. B. Sartain and A. E. Dudeck, "Yield and nutrient accumulation of Tifway bermudagrass and overseeded ryegrass as influence by applied nutrients," Agronomy Journal, vol. 74, pp. 488-491, 1982.

[28] P. M. Kopittke and N. W. Menzies, "A review of the use of the basic cation saturation ratio and the "ideal" soil," Soil Science Society of America Journal, vol. 71, no. 2, pp. 259-265, 2007.

[29] R. J. M. Fitzpatrick and K. Guillard, "Kentucky bluegrass response to potassium and nitrogen fertilization," Crop Science, vol. 44, no. 5, pp. 1721-1728, 2004.

[30] R. H. Bray and L.T. Kurtz, "Determination of total, organic, and available forms of phosphorus in soils," Soil Science, vol. 59, pp. 39-45, 1945.

[31] J. M. Bremner and C. S. Mulvaney, "Total nitrogen," in Methods of Soil Analysis, Part 2, H. Miller and D. R. Keeney, Eds., Agronomy Monograph 9, pp. 595-624, American Society of Agronomy, Madison, Wis, USA, 1982.

[32] C. Y. L. Huang and E. E. Schulte, "igestion of plant tissue for analysis by ICP emission-spectroscopy," Communications in Soil Science and Plant Analysis, vol. 16, pp. 943-958, 1985.

[33] United States Golf Association (USGA), Specifications for a Method of Putting Green Construction, United States Golf Association, Far Hills, NJ, USA, 1989.

[34] P. G. Johnson, R. T. Koenig, and K. L. Kopp, "Nitrogen, phosphorus, and potassium responses and requirements in calcareous sand greens," Agronomy Journal, vol. 95, no. 3, pp. 697$702,2003$.

[35] K. Guillard and W. M. Dest, "Extractable soil phosphorus concentrations and creeping bentgrass response on sand greens," Crop Science, vol. 43, no. 1, pp. 272-281, 2003.

[36] S. M. Houlihan, Soil test selection and calibration for turfgrass in Wisconsin, M.S. thesis, University of Wisconsin-Madison, Madison, Wis, USA, 2005.

[37] T. R. Turner and N. W. Hummel Jr., "Nutritional requirements and fertilization," in Agronomy Monograph No. 32, D. V. Waddington, R. N. Carrow, and R. C. Shearman, Eds., pp. 385-439, American Society of Agronomy, Madison, Wis, USA, 1992.

[38] J. M. Goatley Jr., V. Maddox, D. J. Lang, and K. K. Crouse, “'Tifgreen' bermudagrass response to late-season application of nitrogen and potassium," Agronomy Journal, vol. 86, no. 1, pp. 7-10, 1994.
[39] D. C. Bowman, "Daily vs. periodic nitrogen addition affects growth and tissue nitrogen in perennial ryegrass turf," Crop Science, vol. 43, no. 2, pp. 631-638, 2003.

[40] P. E. McCullough, H. Liu, L. B. McCarty, T. Whitwell, and J. E. Toler, "Bermudagrass putting green growth, color, and nutrient partitioning influenced by nitrogen and trinexapacethyl," Crop Science, vol. 46, no. 4, pp. 1515-1525, 2006.

[41] Davis, "Nutrition and fertilizers," in Turfgrass Science, A. A. Hanson and F. V. Juska, Eds., American Society of Agronomy Series No. 14, pp. 130-150, American Society of Agronomy, Madison, Wis, USA, 1969.

[42] D. V. Waddington, E. L. Moberg, and J. M. Duich, "Effect of $\mathrm{N}$ source, $\mathrm{K}$ source, and $\mathrm{K}$ rate on soil nutrient levels and the growth and composition of Pencross creeping bentgrass, Agrostis palustris Huds," Agronomy Journal, vol. 64, pp. 562$566,1972$.

[43] J. R. Hall and R. W. Miller, "Effects of phoshorus, season and method of sampling on foliar analysis of Kentucky bluegrass," in Proceedings of the 2nd International Turfgrass Research Conference, E. C. Roberts, Ed., pp. 198-209, American Society of Agronomy, 1974.

[44] M. Y. Siddiqi and A. D. M. Glass, "Simultaneous consideration of tissue and substrate potassium concentration in the $\mathrm{K}^{+}$ uptake kinetics.: a model," Plant Physiology, vol. 69, pp. 283$285,1982$.

[45] C. Engels and H. Marschner, "Plant uptake and utilization of nitrogen," in Nitrogen Fertilization in the Environment, P. E. Bacon, Ed., pp. 41-81, Marcell Dekker, New York, NY, USA, 1995.

[46] K. Lajtha and A. F. Harrison, "Strategies of phosphorus acquisition and conservation by plant species and communities," in Phosphorus in the Global Environment, H. Thiesen, Ed., chapter 8, John Wiley \& Sons, New York, NY, USA, 1996. 


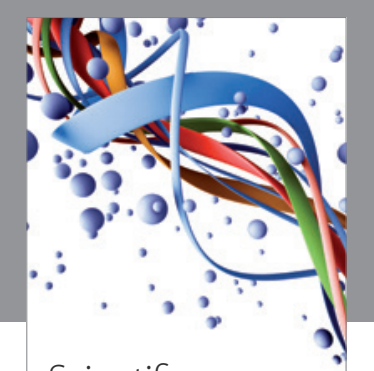

Scientifica
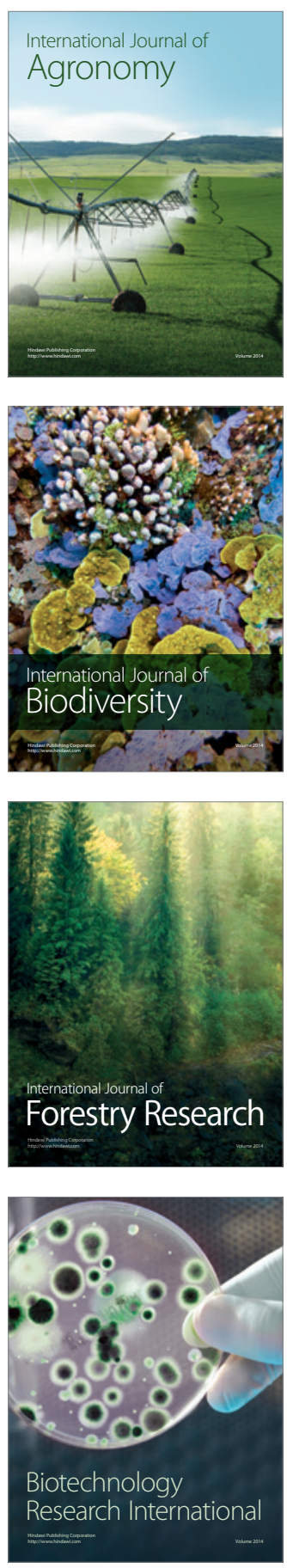
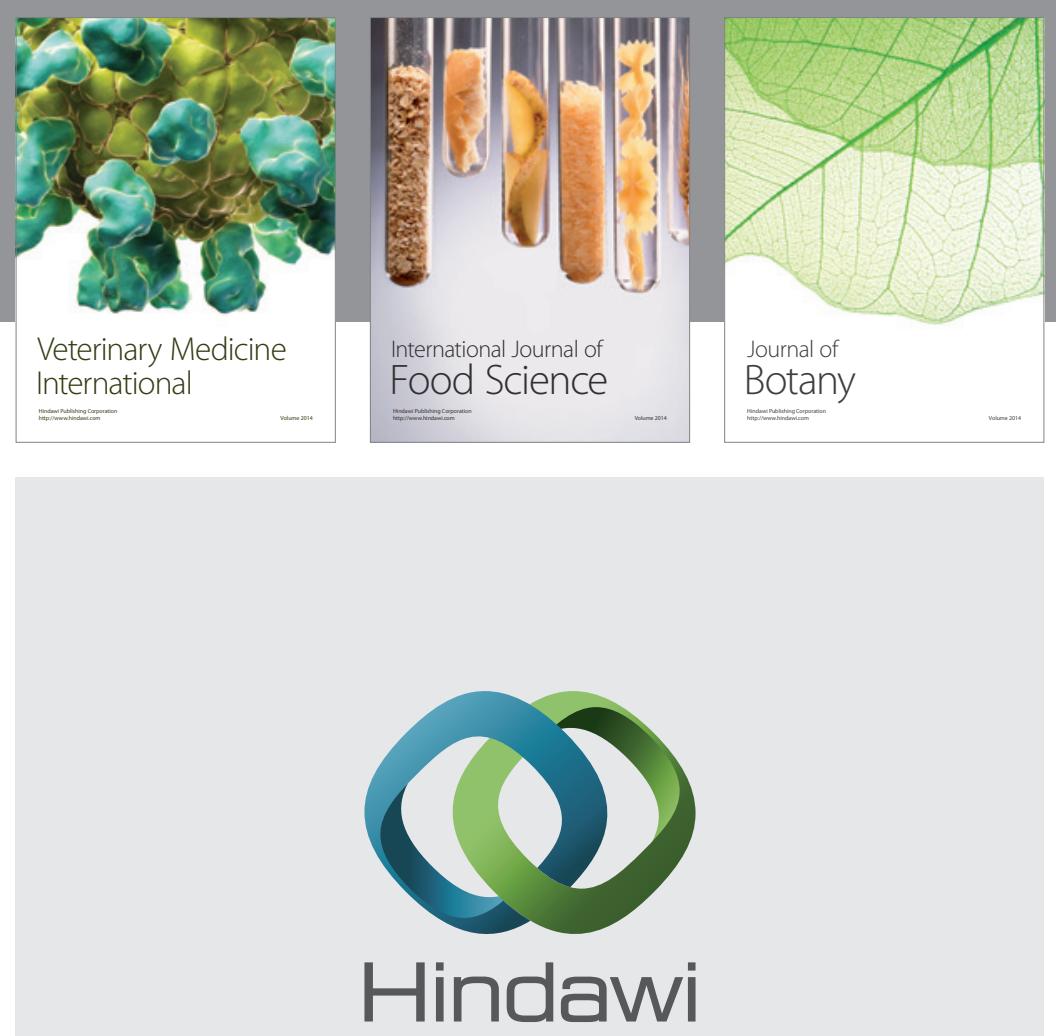

Submit your manuscripts at

http://www.hindawi.com
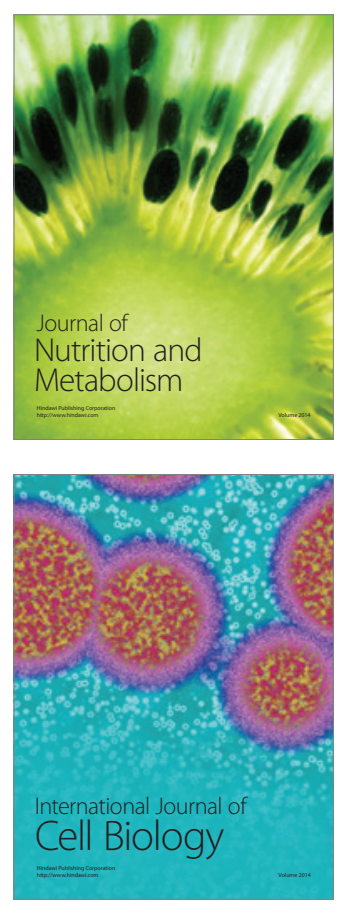
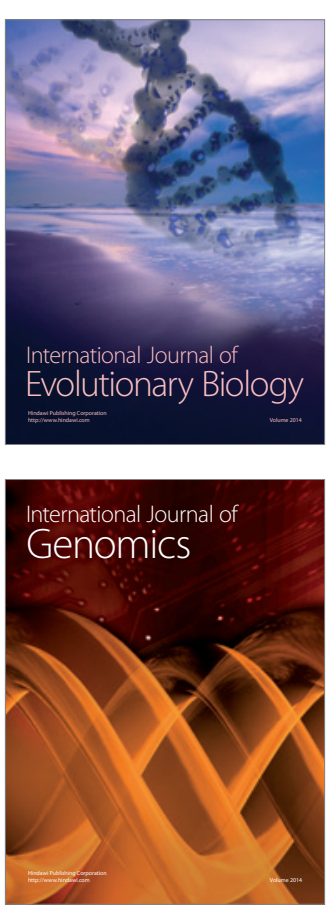
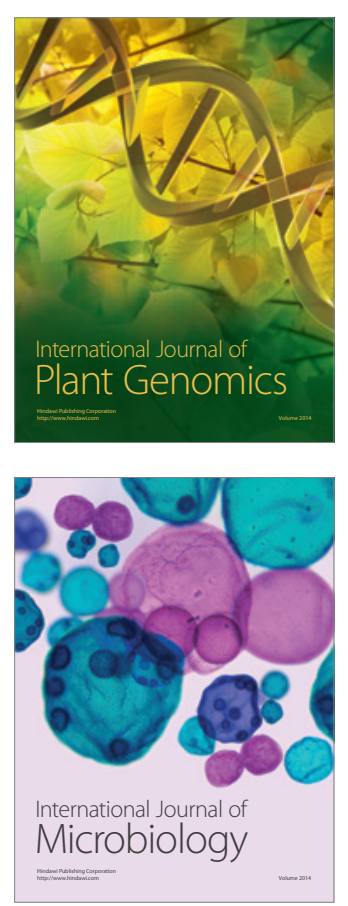

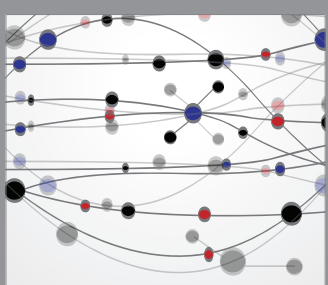

The Scientific World Journal
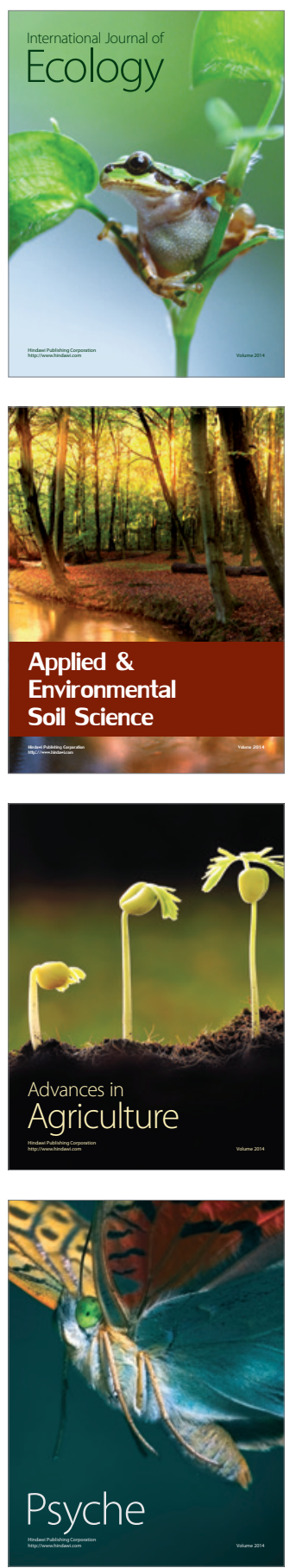